\title{
Tourism-Dominated Spaces - The Strategic Potential of Hotel Lobbies
}

\author{
By Jens Christian Pasgaard ${ }^{*}$
}

Today, tourism has become a crucial factor in urban economies, and the extended presence of tourism facilities within the urban fabric has generated a new basis for planning decisions. However, the phenomenon of tourism has primarily been discussed by sociologists, ethnologists, geographers and not least by economists. The architectural voice in the general tourism-related discussion, in a very wide sense, has been relatively vague. The aim of this article is to discuss the strategic potential of a specific tourism programme, namely the hotel lobby as well as the immediate urban context of this lobby. From a qualitative architectural point of view the article examines the evolution of specific lobby-qualities at Miami Beach; from the pre-war Art Deco hotel lobby to the post-war MiMo ${ }^{1}$ resort lobby. In particular, the study highlights 'extraordinary' qualities of tourism-dominated spaces (as opposed to 'ordinary' everydaydominated spaces). The article addresses the phenomenon of tourism at a very local planning level, and touches on the concept of 'positive interference'. Positive interference is understood as the friction between tourism-related and everyday-related activities and is launched as a 'potential desirable quality' of the tourismdominated space. Overall, the article points towards an untapped strategic planning potential of specific architectural tourism-related programmes. (This article is rooted in theories presented in the PhD-dissertation Tourism and Strategic Planning which was defended in October 2012).

\section{A Note on Concepts and the Overall Approach to the Phenomenon of Tourism}

This paper features a number of much discussed concepts related to the complicated phenomenon of tourism and to the discipline of strategic urban planning. It is beyond the scope to enter into a detailed discussion of all mentioned concepts; however, it is important to set the stage by providing a few compressed notes on the overall approach to tourism-dominated spaces and potentially desirable qualities of these spaces.

*Post Doctoral Research, The Royal Danish Academy of Fine Arts, Denmark.

${ }^{1}$ The term MiMo refers to the so-called architectural style Miami Modernism. 
Generally, from a qualitative architectural perspective, the technical determinations of how to define tourists and tourism businesses ${ }^{1}$ become less important compared to a discussion of tourism behaviour and the spaces which frame this behaviour.

What is essential here is to understand that tourism behavior and tourist space are fluid and relative concepts. Corresponding to the fluid transition between chores of everyday life and tourism behaviour, the tourist space is not an unequivocal spatial specification. Rather, tourist space is a temporary condition, which is dependent on tourism activity and the mode of the observer. As such, the character of the space is determined by the prevailing behaviour as well as the physical frame, which stimulate this behaviour.

Consequently, it seems more accurate to use the term tourism-dominated space (as opposed to the everyday-dominated space) rather than the more categorical term tourist space.

In a qualitative study, as the one presented here, the liquidity of the tourism phenomenon is not seen as a limiting factor, but rather as a potential. In other words my objective is to acknowledge and explore the diversity and multiplicity associated with the tourism phenomenon.

Situation: The Tourism-Dominated Spaces and Networks are Expanding

Over the last couple of decades we have seen an extensive virtual and physical time-space contraction. The global network society has become a reality, and according to the sociologist John Urry there is "no evidence that virtual and imaginative travel is replacing corporeal travel" (2002: 141). Instead, the different modes of travel "are increasingly de-differentiated from one another" (ibid.: 141). The result is that we (the educated middleclass), are increasingly on the move, both virtually and corporeally. Zygmunt Bauman has portrayed a world in which "life itself turns into an extended tourist escapade" and where "tourist conduct becomes the mode of life" (Bauman, 1996: 30). The global mobility is constantly enhanced in all senses. Urry explicates:

\section{Because of these liquidities the relations between almost all societies across the globe are mediated by flows of tourists, as place after place is reconfigured as a recipient of such flows. There is an omnivorous producing and 'consuming [of] places' around the globe (see Urry 1995). Core components of contemporary global culture now include the hotel buffet, the pool, the cocktail, the beach (Lencek and Bosker, 1998), the airport lounge (Gottdiener, 2001) and bronzed tan (Ahmed, 2000). (Urry, 2002: 141)}

What is central here is that more and more spaces are impacted by tourism-related flows and thus tourism-related challenges. However, the tourism-dominated networks are not just expanding; in addition, they seem to divide the cities into tourism-adapted and non-tourism-adapted spheres. The urban planner Jens Kvorning has described this division as a "spatial

\footnotetext{
${ }^{1}$ As provided by The United Nations World Tourism Organization (UNWTO).
} 
structuring in the form of segregated and segregating networks" (2010: 75). The result is urban fabrics, where certain corridors or sequences of spaces are specialised to meet the flows of zapping 'post-tourists', whereas other corridors are completely drained from tourist-related activities.

\section{The Formulation of Qualitative Demands}

Taking these circumstances into account, it becomes essential to pose qualitative demands for these increasingly comprehensive and dividing tourism-dominated networks. First of all it is important to make sure that tourism is not overtaking spaces. According to several academics tourism is simply 'leaving out a lot of possibilities', resulting in a loss of spatial experiments and in a rejection of antagonistic ideas ${ }^{2}$. Therefore, from an urban planning perspective, it seems important to secure that tourism-dominated spaces can accommodate very different modes of behaviour. Or, in other words: it is important that the spaces can accommodate and benefit from both tourism-related and non-tourism-related activities, a spatial quality, which in the following will be characterised as positive interference.

The underlying premise of the following discussion is that positive interference generally speaking is 'good' - a potentially desirable quality of the tourism-dominated space (Pasgaard, 2012).

\section{Miami Beach. An Example of Positive Interference}

The following paragraphs take a deeper look into a specific form of positive interference which occurred in and around luxurious hotels and resorts at Miami Beach in the period from the late 1940s to the early 1970s, frequently referred to as the 'golden age of American capitalism'.

The overall development of Miami Beach, from mangrove swamp to a global tourism hotspot, is a story about dramatic shifts between construction and destruction. The present-day version of Miami Beach is the result of a repetitive cyclical process where massive tourism-related investments in times of prosperity have been followed by abrupt bankruptcies as a consequence of crashing real estate markets or devastating hurricanes. A time where the bankruptcies have led to transfers of ownerships accompanied by still more impressive capital injections. It is also a story about colourful personalities, in form of risk-taking entrepreneurs, powerful hotel managers, and avant-garde architects, who all were acting within a very liberal planning system that provided them with great freedom to manoeuvre and to develop a number of extraordinary hotels.

\footnotetext{
${ }^{1}$ The concept of a post-tourist has been described by Feifer (1985).

${ }^{2}$ For instance stated by the ethnologist Orvar Löfgren in his presentation 'Shopping malls as public domains' at the conference: Public Domain \& Fun Scape - Urban Space in the Network City, held in Aalborg (Denmark) in 2005.
} 
Before concentrating on the lobby, a few comments on how Miami Beach was constructed are provided in order to give an understanding of the overall context and to describe how specific lobbies came to play a role in an increasingly international tourism market.

\section{Dream Construction - The Foundation of an Urban Well-Connected Seaside Resort}

In the late $19^{\text {th }}$ and early $20^{\text {th }}$ century, several aborted attempts had been made to cultivate the isthmus between Miami's Biscayne Bay and the Atlantic Ocean. Early pioneers had begun to lose faith in the marshy and mosquitoinfested barrier island, situated inconveniently 2-4 kilometres from the mainland. However, the steadily expanding networks of railroads throughout Florida, and in particular, the construction of the east coast connection to Miami, completed in 1896, made the whole Biscayne Bay area increasingly attractive.

Eventually, a handful of visionary people managed to activate the strip of land by constructing an impressive wooden bridge and not least by changing their business agenda from unsuccessful farming to real estate and tourism development (see e.g. Camber, 2001). A key person in this process was the entrepreneur and motorsports enthusiast Carl G. Fisher (1874-1939) who invested extensively in the risky project. Fisher obtained control of roughly 1.8 $\mathrm{km}^{2}$ of land at the southern end of the isthmus stretching from the bay to the Atlantic Ocean (McCarthy, 1975). From the very outset, Fisher dreamt of transforming the strip of land into an urban winter-vacation resort. Fisher's wife has recalled the couple's first visit to the isthmus in 1912, where she was dragged through the mangrove swamp in white shoes, and Fisher had exclaimed: "Look, honey, I'm going to build a city here! A city like magic, like romantic places you read and dream about, but never see." (McCarthy, 1975).

What was remarkable was that Fisher's dream was urban. He was not dreaming of a romantic scenic seaside resort - he was dreaming of a pulsating magic city situated at the sea. Fisher wanted to construct an "American Riviera", which could attract the rising number of American millionaires (Camber, 2001). It was not just a tourism strategy; it was just as much a settlement strategy.

Hereby, the tourism industry's usual mantra of creating reasons to go was supplemented by creating reasons to stay. Fischer wanted to create a frame which could tempt people to stay for much longer time or even permanently. In this way Miami Beach was significantly different from earlier developed northern seaside resorts which to a great extent were dominated by large-scale entertainment structures in form of pleasure piers and amusement parks ${ }^{1}$.

To fulfil this dream, Fisher and his co-developers undertook a number of operations: mangroves were cleared, sand from the Bay was dredged and used to stabilise the beaches, new residential islands were constructed in the bay, internal canals were created, central streets were laid out, and a few hotels,

${ }^{1}$ For instance Coney Island and Atlantic City in the U.S.A. or Brighton and Blackpool in the U.K. 
nightclubs and casinos were built in connection to a new leisurescape consisting of parks, golf courses, polo fields and small new marinas. All in all, an incredible amount of money was invested in the physical transformation and all was done before the developers had any form of return on investments ${ }^{1}$.

In the first years, the development was moderate. Consequently, in order to accelerate development, the key actors launched several strategic initiatives: they coordinated a nationwide tourist campaign; they offered free lots to attract selected residents and new hotel investors; they arranged polo events with invited British polo players in order to add some glamour to the site; etc. A few years later, after World War I, the efforts of the pioneers were finally rewarded when Miami Beach became the focal point of the great Florida Land Boom of the mid-1920s ${ }^{2}$.

An important aspect of the overall development was that from the very beginning, Miami Beach became closely connected to Miami Metropolitan Area. In that way Miami Beach benefitted from being linked to a harbour which could receive cruise ships and an airport, which, as early as the mid1930s, had daily services to New York and Chicago and was functioning as an early-developed hub for flights towards Central and South America ${ }^{3}$. This accessibility was important in order to attract a relatively mixed audience and in order to establish a cosmopolitan atmosphere - a crucial ingredient in Fisher's dream of constructing an American Riviera.

\section{The Hotel Lobby Becomes Inscribed in a Still Denser and More Urban Fabric}

Described in-depth by the Miami-based architect Allan T. Shulman, the urban character and spatial evolution of Miami Beach was an outcome of a long range of interfering urban and architectural layers (2001: 8-39). For the purpose of this article, it is too comprehensive and complicated to get into details of all of these layers, but it is important to address the basic layer, namely the grid.

Simplified, the urban plan of Miami Beach can be described as tree interconnected grid-systems, which were laid out by the three initial key developers in the 1910s (Fig 1, 2 and 3).

\footnotetext{
${ }^{1}$ See e.g. McCarthy's description of the physical transformation process (1975).

${ }^{2}$ Most of abovementioned strategic initiatives have been described by McCarthy (1975).

${ }^{3}$ Companies like the Eastern Airlines and the Pan American World Airways had regular flights to and from Miami in the 1930s.
} 
Figure 1. A Section of the Southern Part of the Peninsula with the Characteristic 15.2-Meter-Wide Lots (The Lummus Brothers' Layout). Aerial Photograph with Dotted Grid-structure

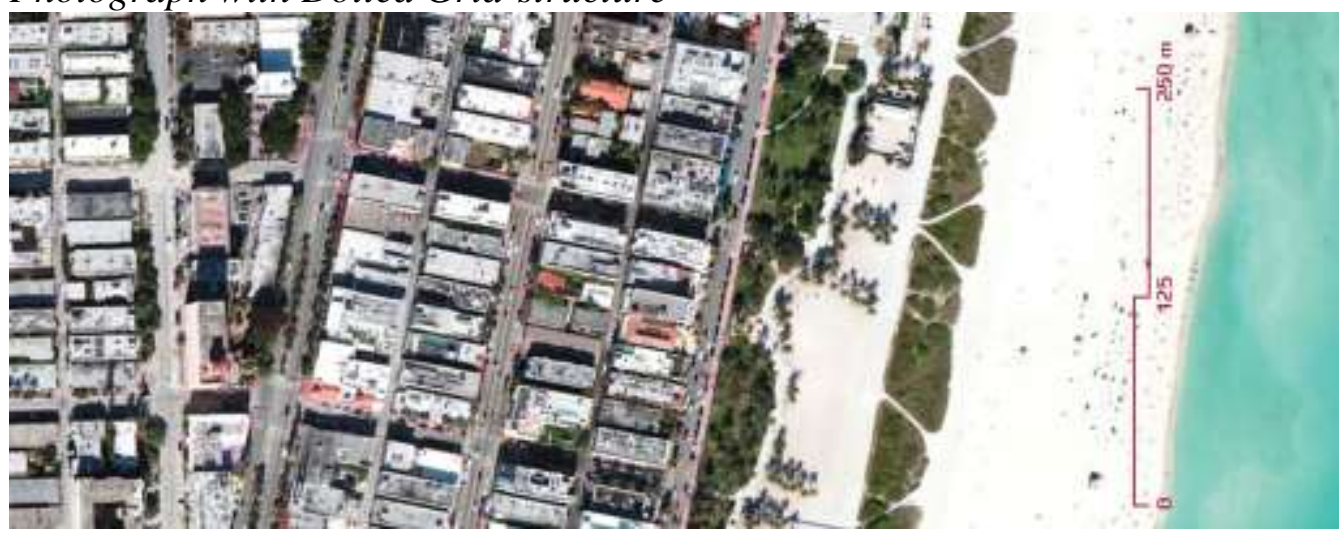

Figure 2. A Section of the Central Part of the Peninsula with Narrow but more Generously Proportioned Lots (Fishers' Layout). Aerial Photograph with Dotted Grid-Structure

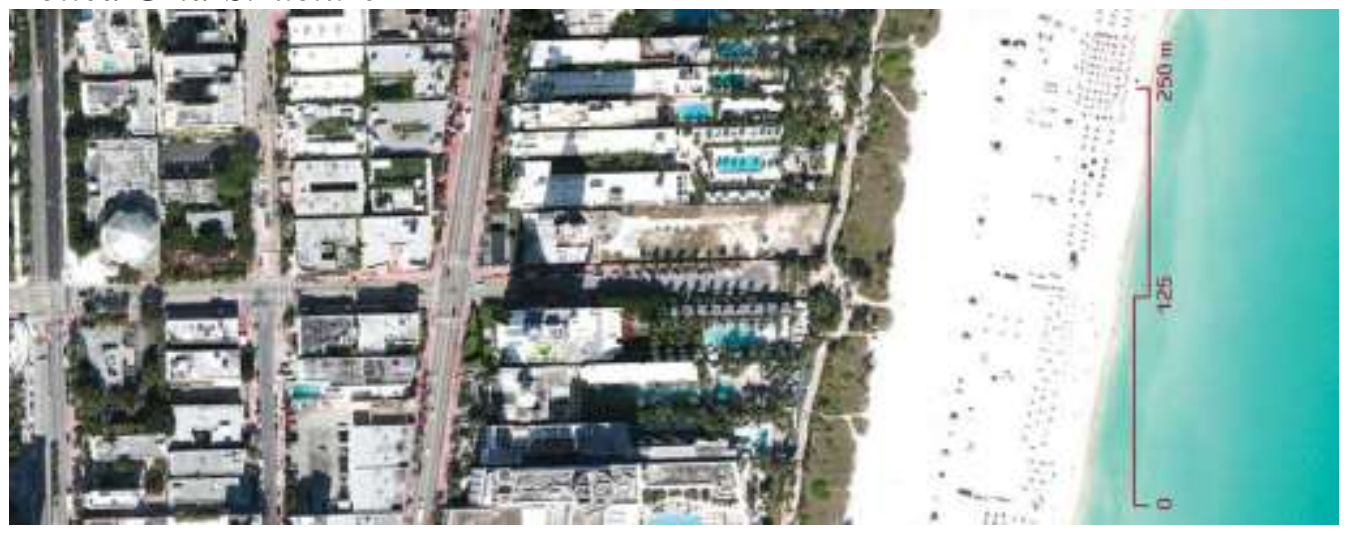

Figure 3. A Section of the Northern Part of the Peninsula with much Wider Lots (Collins' layout). Aerial Photograph with Dotted Grid-Structure

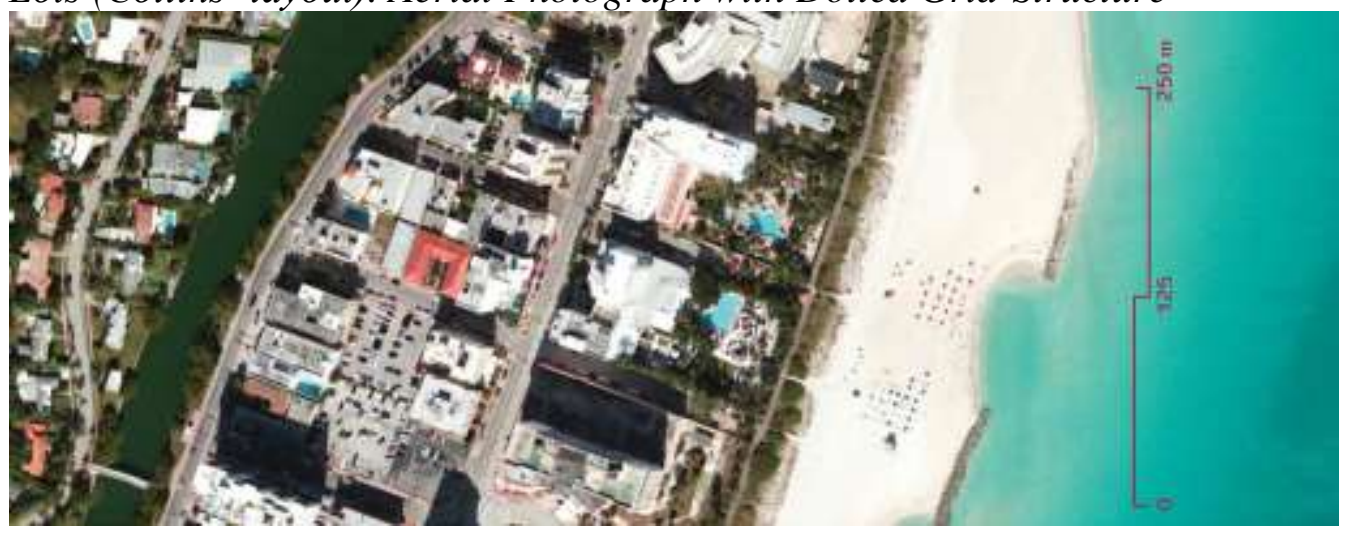


The three grids produced different rhythms which proved to be very flexible in accommodating the changing demands of the tourism business. Collectively, it was a layout providing great variation in lot sizes, from the 15meter-narrow lots in the South Beach area to the more than 100-meter-wide lots along Collins Avenue at the northern part of the peninsula. This lot size variation meant that dissimilar development scenarios could be in progress simultaneously in different areas of the peninsula. During times of prosperity, the mid-beach properties were ideal for large-scale projects; whereas, during times of recession, the south-beach properties were ideal for small-scale interventions (often in form of reprogramming - in the way that small-scale hotels were converted to rental apartments and also vice versa). In other words, a differentiated grid-structure made room for quite different spatial dynamics. The overall compactness of the grid-structure along with very liberal building regulations (before access to sunlight and preservation became important issues) stimulated a general process of densification and an increasingly lifegiving spatial complexity.

The urban character was also a consequence of Fischer's dream of constructing a city. Fisher had from the beginning implemented 'European qualities', such as squares, galleries and pedestrian ways, into the archetypal American grid-structure (Fig. 4 and 5). Further the ambition of creating a real functioning city meant that the tourism-related programmes were supplemented by several non-tourism-related programmes.

Figure 4. Lincoln Road. A Centrepiece in Fisher's Grid-Structure. The 30Meter-Wide Pedestrian Shopping Street forms a Cultural and Commercial Gathering Point - A Centre with an Urban Congestion that Stimulates a LifeGiving Flow in the Adjacent Streets. Aerial photograph

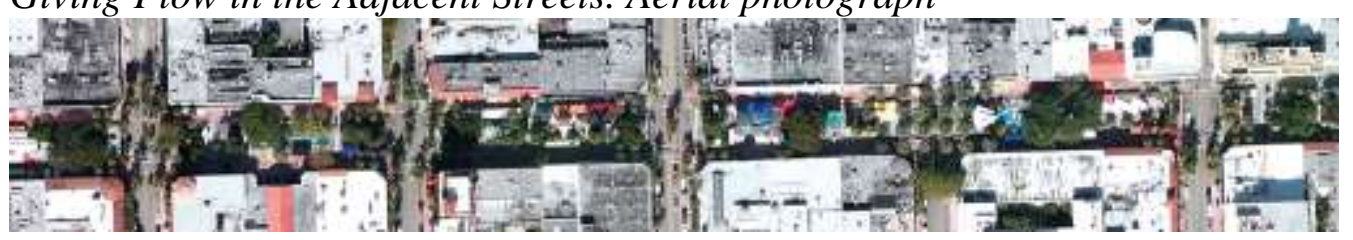


Figure 5. Lincoln Road. Photo: July 04, 2008

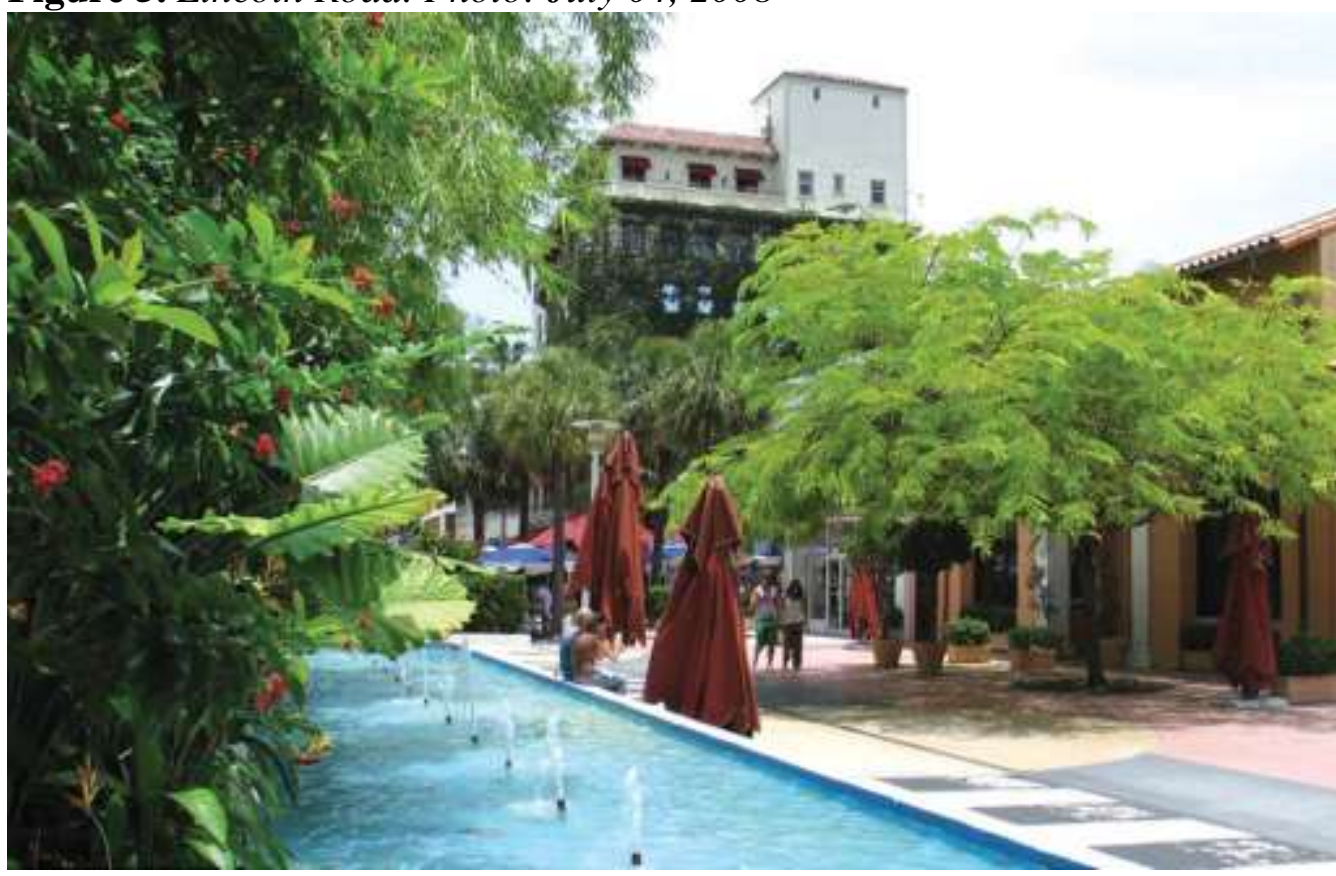

\section{The Art Deco Lobby}

The overall 'urbanity' had a positive impact on Miami Beach's hotel designs, which were more complex than were those in many other seaside resorts. Many Miami Beach hotels were composed as a kind of hybrid oriented both towards the ocean and towards the urban street (Fig. D-30, see also Shulman, 2001: 21). This compositional characteristic became important in relation to the role played by the hotel lobby.

Even the earliest Art Deco hotels of Miami Beach had noteworthy lobby floors. The plain reason for this, according to William $\mathrm{H}$. Cary from the City of Miami Beach, was that the first hotels did not have air-conditioning ${ }^{1}$. In a tropical humid climate, it was usually too hot to rest in private hotel rooms without access to balconies. Consequently, the lobby areas came to function as important living rooms for the guests. And, as Miami Beach grew more dense and urban, the hotel lobby came to function as a sort of urban living room. Many lobby floors were accessible 24 hours a day and fulfilled several functions for both guests and non-guests: in the morning passers-by could stop to have a cup of coffee and read the newspaper in the lobby cafés; at lunch and dinner time the lobby gave access to (often several) restaurants; and, in the evening, many lobbies turned into actual nightclubs. In this way the lobby became an important place to socialise. It had become a tourism-dominated space inscribed in an urban fabric that delivered an increasingly dense mix of hotels, apartment-blocks, retail shops and public service functions. The lobby became an interface between the beach life and the urban street life - a

\footnotetext{
${ }^{1}$ Information from an interview with William H. Cary held in Miami Beach, 2008. William H. Cary is Division Director for Historic Preservation (City of Miami Beach).
} 
tourism-dominated space positively impacted by both everyday-dominated and business-dominated local and international flows.

Lobby Evolution - From Art Deco Hotels to MiMo Resorts

Beginning in the late 1920s, the world saw the emergence of a new kind of holiday concept: the total resort'. The 'total resort' or 'resort hotel' is a qualitative term describing a large-scale hotel complex situated in a 'vacationscape' - a designed garden loaded with pleasure facilities (tennis courts, badminton courts, swimming pools, spas, etc.). The resort hotels provided a new kind of all-inclusive territory and became soon a destination in itself.

Two decades later, just after World War II, the resort hotel arrived at Miami Beach, where it immediately became a dominant tourism typology. The emergence of the new resorts coincided with the entrance in the third era of economic growth at Miami Beach. Due to well-known factors - the general rise in the standard of living, the still more affordable car, and the fast-growing aviation industry, etc. - the growth era lasted for almost 25 years. The growth was further fuelled by the fact that most post-war hotels introduced airconditioning in the hotel rooms. This technical improvement caused a transformation of Miami Beach from a typical winter resort to an all-yearround destination. The market seemed in insatiable. It was in this optimistic climate that a new generation of hotel developers and architects were acting.

The majority of these resort hotels were constructed in an architectural style which later became known as MiMo or Miami Modernism. Stylistically, MiMo-resorts followed the Art Deco-hotels with spatial setbacks, rounded corners, etc.; however, they were generally upscaled and much larger structures. There were often pronounced differences between the interiors and the exteriors. From the outside, the MiMo-resorts appeared cleaner than their stylistic predecessors. The facades were characterised by strict horizontal lines with relatively few ornamental details. In contrast, the interiors were often playfully eclectic compositions.

Although the new generation of MiMo-resorts had air-conditioned rooms, they continued the tradition of using the lobby floor as an extended living room. In fact, the lobby floors were constantly enlarged and became steadily more sophisticated.

\section{The Hedonistic Territory of the Fontainebleau Hotel}

This last paragraph on Miami Beach will look deeper into the spatial design of the lobby floors of one of the most legendary MiMo-resorts, namely the Fontainebleau Hotel. In 1952, the charismatic hotelier and businessman Ben Novak commissioned the architect Morris Lapidus to design an unprecedented luxury hotel at a very wide and attractive parcel on Collins Avenue frequently referred to as the 'millionaire's road'. The assignment

\footnotetext{
${ }^{1}$ According to Orvar Löfgren, the idea of the resort hotel originated from Waikiki Beach on the island of Oahu in Hawaii, where the 400-room Royal Hawaiian hotel opened in 1927 (Löfgren, 1999: 249).
} 
was to combine a contemporary exterior with a thematised, so-called 'French Provincial' interior.

The equally modern and Baroque Fontainebleau was designed as a number of semicircles and soft, free-flowing curves, which linked and framed interfering interiors and exteriors: the curved hotel-tower framing the view and the garden; the curved entrance embedding the imposing driveway (adapting adaption to a new urban rhythm dominate by the open cars); the at-the-time largest open-lobby area in Miami Beach linking the amorphous ballroom, the garden lobby and the circular supper club with the oval stage; and finally, the two-story, waved 'cabana-structure' sectioning the large garden to create intimate corners in a flamboyant tropical pool garden where the guests were promenading. This was a good place to socialise - to see and to be seen. (Fig. 6 and 7).

Figure 6. The Fontainebleau Hotel (with The Eden Roc Hotel in the background). Constructed 1952-54. The Iconic curved 550-room Tower Marked a New Era, where more Money than Ever before was put into Resort Construction. Everything was magnified. The Photo from 1955 is Reproduced with kind Permission from the Copyright Holder: The Morris Lapidus Papers, Special Collections Research Center, Syracuse University Libraries

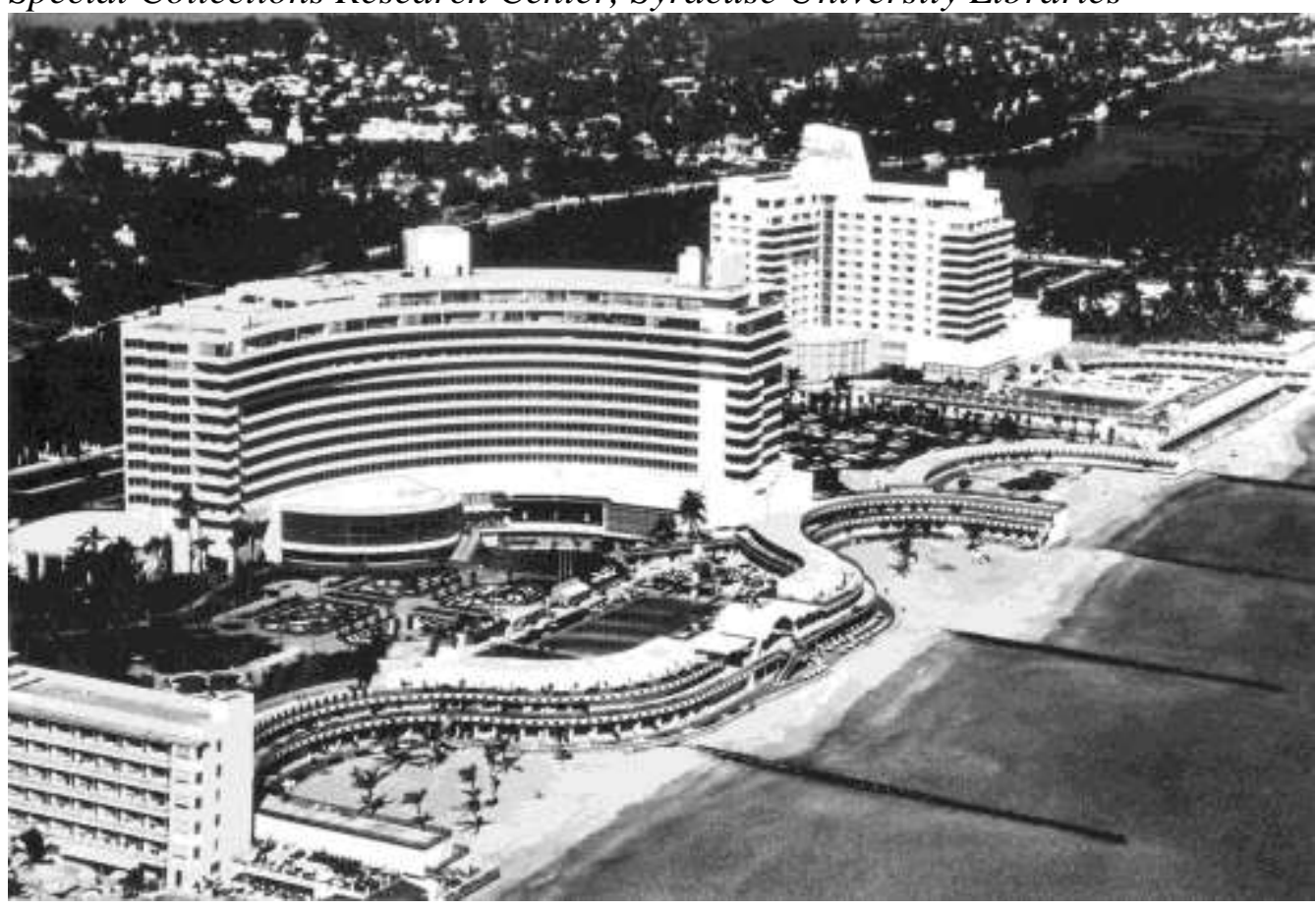


Figure 7. Main Lobby Floor Plan of the Fontainebleau Hotel. The Plan is Reproduced with kind Permission from the Copyright Holder: The Morris Lapidus Papers, Special Collections Research Center, Syracuse University Libraries

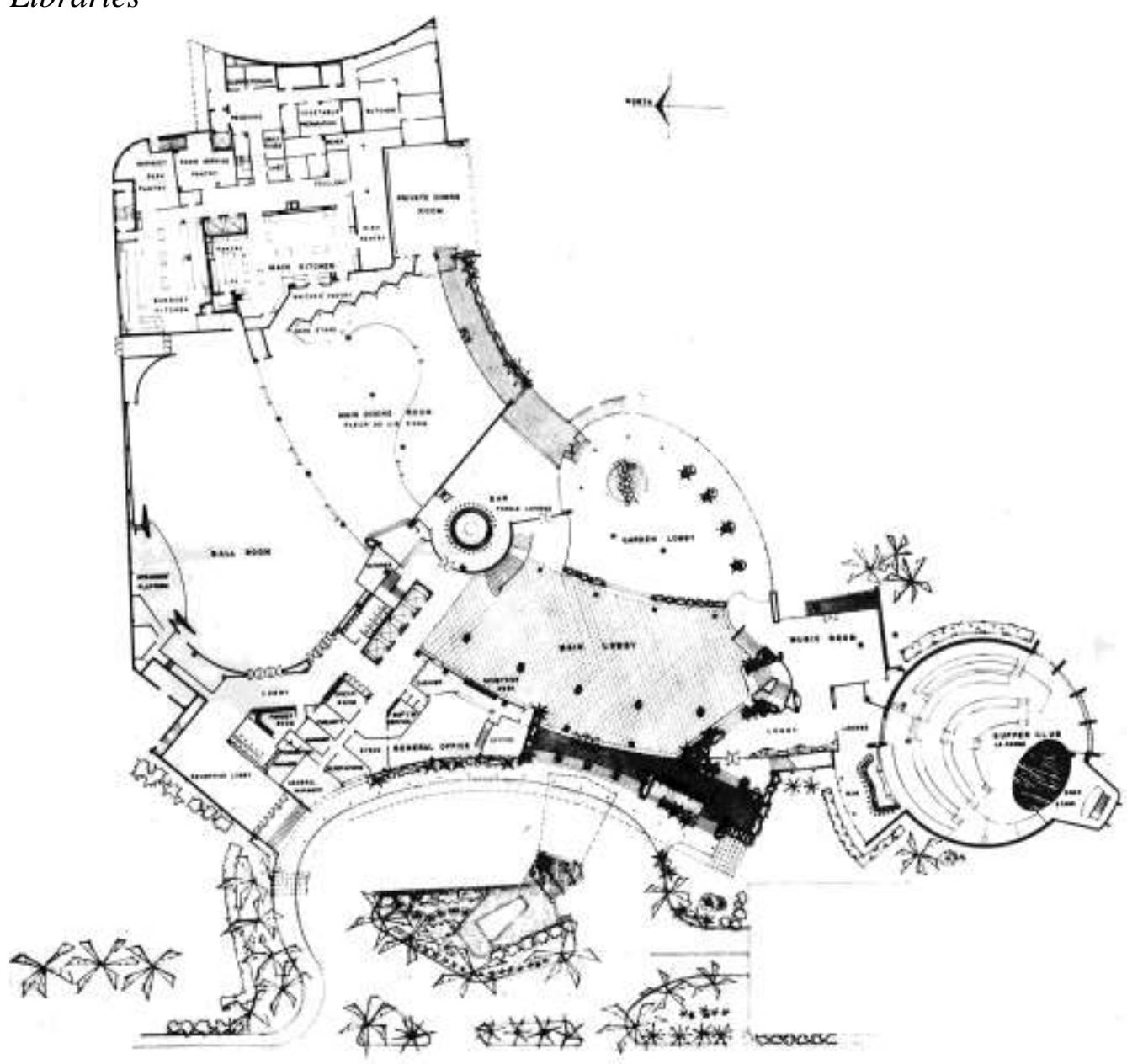

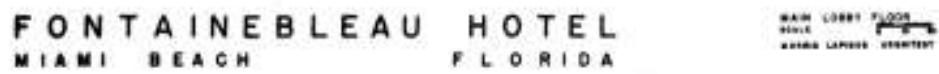

Lapidus pursued the spatial transitions and this was where he prioritized spending money: the driveway, the entrances and the reception, the promenades, the doorways and not least the linking steps and stairs. The famous and frequently portrayed 'staircase to nowhere', , a key component of the lobby, illustrated his general design approach (Fig. 8). The grandiose staircase originally led only to secondary functions and a coat check (in the tropical climate), but the female guests entering the lobby from their hotel rooms typically left the elevator on the second floor in order to descend the staircase $^{2}$ and make an appearance in the lobby. Lapidus always designed curved, illuminated staircases to enforce the important moment for the

${ }^{1}$ Mentioned in several sources (e.g. Cook and Klotz, 1973; Düttmann, 1992; Lapidus, 1996).

${ }^{2}$ Described by Plotner and Plotner (2008: 35). 
descending lady: her evening dress should be visible from various angles, she should feel important and she should be able to return a gentleman's gaze through the large open space. It was all a cinematic staging of emotional tensions. It was staged flirting - implemented throughout the hotel - with evocative, mysteriously orchestrated settings leading the guests from space to space, from terrace to terrace, during the day, evening and night. Women in bathing suits were visible through large underwater pool windows and men showed off at exceptionally high diving platforms.

Figure 8. The Famous 'Staircase to Nowhere' from the Fontainebleau Hotel. The Photo is Reproduced with kind Permission from the Copyright Holder: The Morris Lapidus Papers, Special Collections Research Center, Syracuse University Libraries

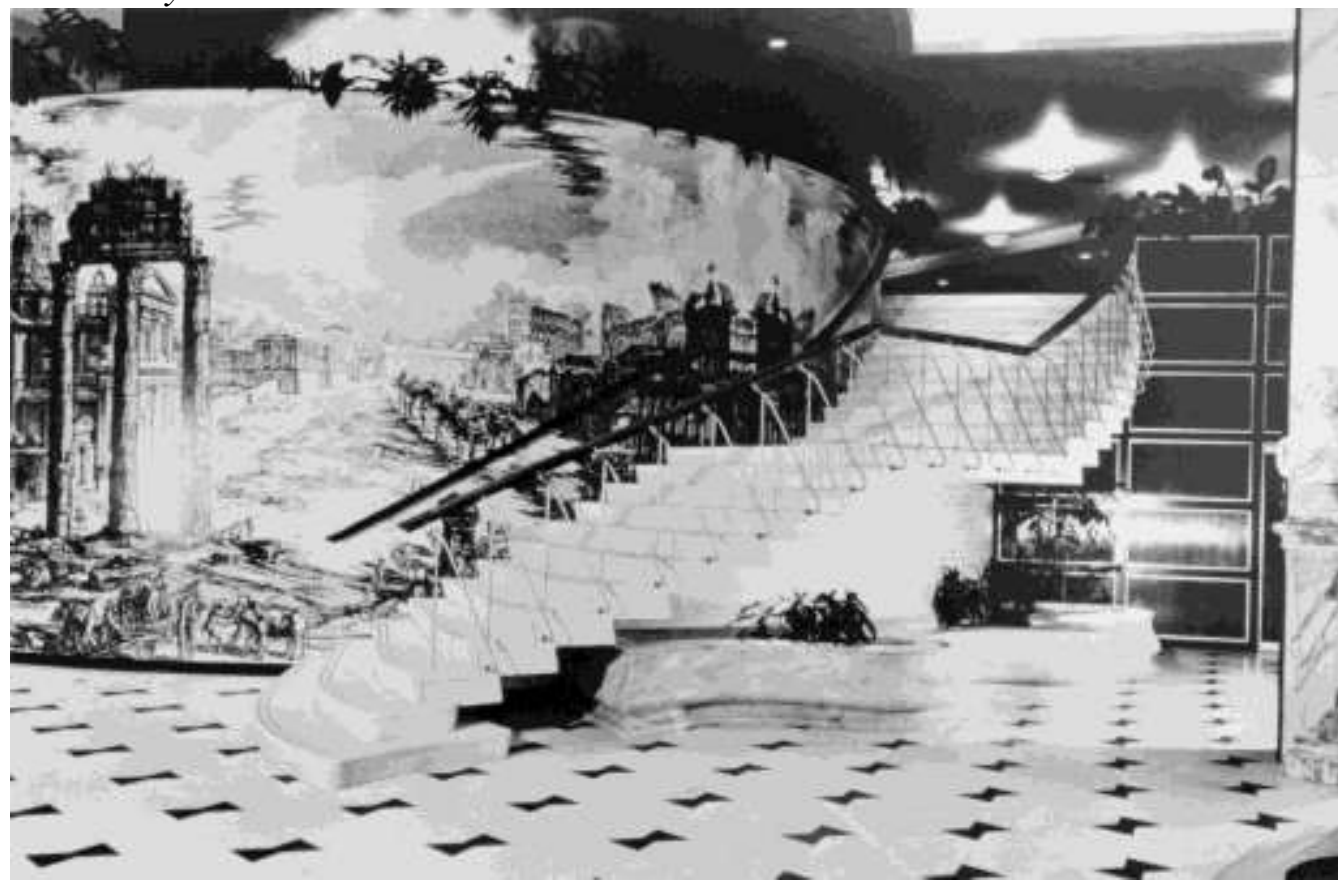

The Fontainebleau was an immediate commercial success and presented an unparalleled hedonistic territory with the capability to attract the newly born jet set. Fontainebleau became a sophisticated, exotic party ground for business moguls, celebrities, and movie stars. In the wake of the jet set followed a large crowd of people from the upper middleclass. The Fontainebleau was significantly larger than the prototype hotel in Miami Beach and had the lucrative capacity of joining extravagant luxury with mass consumption.

This was the place to be in order to chill out and in order to be introduced to the right people. The resorts delivered a seductive mix of business and pleasure. It was a territory where normal resort practices were smoothly blended with illegal gambling (conducted in 'private rooms'), elegant prostitutes (who frequented the lounges) and shady business deals (that were 
carried out in the cabanas $)^{1}$. These more questionable activities matched perfectly the 1950s perception of glamour: it was luxury blended with a dark, mysterious underworld ${ }^{2}$.

\section{An Era Ends}

Present-day Miami Beach is still a vibrant tourism hotspot; however, I will argue that an important epoch ended in the late 1960s, when Ben Novak took the decision to keep 'gawkers' out of the hotel ${ }^{3}$. At this time Fontainebleau had become a major attraction, and large numbers of sidewalk strollers were entering the hotel just to see what was going on (see e.g. Plotner and Plotner, 2008: 60-64). To get rid of these 'lobby lizards', Novak established a guarded entrance and simply fenced the property off to non-guests (ibid.). From this stage, the tourism business in Miami Beach entered a difficult patch, and the Fontainebleau Hotel also entered a downward spiral. Ben Novak was forced to file for bankruptcy in 1977.

What is significant here is that many resort hoteliers followed Novak's example. From the 1970s onwards many luxury lobbies were closed off and were only accessible for a limited, privileged audience. Privacy had become a luxury asset - and the ground floors became steadily more introverted domains. This meant that the lobby to a great extent lost its function as an urban living room. The result was that a long range of extraordinary territories were detached from the street life which surrounded them. And consequently, the lobby-based positive interference faded.

\section{Conclusion}

In this concluding chapter, I will attempt to deduce two spatial extracts from Miami Beach. Not with the intention to create a strategic vocabulary generally applicable for tourism-related planning problematics; rather with the intention to facilitate a more multifaceted spatial discussion of the tourism phenomenon. I will argue that the two spatial extracts, presented and elaborated below, point towards a number of central thematic discussions relevant in contemporary urban planning. I will argue that the most important lessons concern what I will call flexible grid-structures and Urban Lobbies and Hedonistic Territories.

\footnotetext{
${ }^{1}$ The criminal activities at Fontainebleau are described in several sources (e.g. Plotner \& Plotner, 2008: 40-44).

${ }^{2}$ Alice T. Friedman (2000) has described how the American perception of glamour changed during the 1940s. In the cinemas, superficial comedies were losing ground in favour of "dark portrayals of the underside of the Hollywood fantasy". Accompanied by the new mass media, the notion of glamour became much more complex.

${ }^{3}$ A 'gawker', diverted from to gawk, is according to The Free Dictionary "a spectator who stares stupidly without intelligent awareness" (http:/www.thefreedictionary.com/gawker).
} 
Flexible Grid-Structures

Figure 9. A Hypothetical Example. The Principle Plan Describes the Three Different Grid Rhythms in Miami Beach Providing very Different Oceanfront Lots. 'Flexibility' Relates both to the Varying lot Sizes and to the Liberal Building Codes

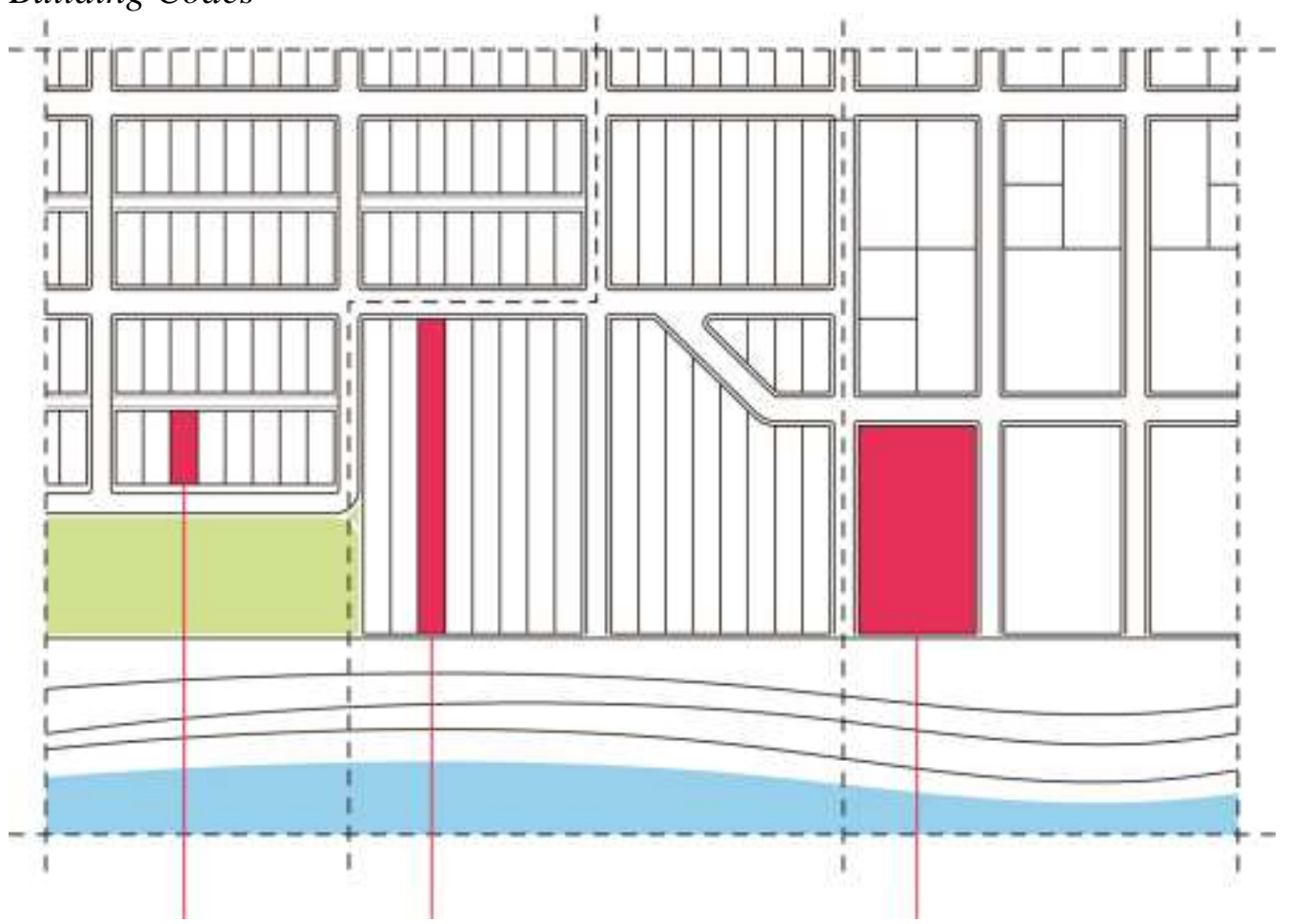

The development of Miami Beach shed light on the potential of urbanity and flexible grid-structures. In relation to the urbanity, it was crucial that Fisher and his co-developers dreamt of constructing an 'American Riviera'. As a result of this dream Miami Beach strived from the beginning to be a luxuryoriented seaside city. In order to make the dream come true the early pioneers invested an incredible amount of money in the physical transformation of the isthmus. Especially in infrastructural projects, which at a very early stage inseparably connected Miami Beach to mainland Miami. It was a strategy, which implied that the region as a whole was developed into a tourism hub serving a cosmopolitan audience.

Another important aspect of the process of site preparation was that the three key pioneers laid out three interconnected grid-structures providing plots in very different scales and proportions. These grid-systems proved to be very flexible in accommodating the changing demands of the hotel businesses. Art Deco hotels conquered the narrow oceanfront lots at the South Beach area and the MiMo resort hotels conquered the wide oceanfront lots at the North Beach area. All in all, it was a differentiated layout which made room for quite different spatial rhythms and dynamics. While the narrow lots - generating streets packed with narrow lobby entrances - stimulated a local pedestrian- 
dominated flow, the wide lots - making space for pretentious driveways stimulated a car-dominated flow.

The flexibility of the grid-structures was further enhanced by the very liberal building codes, which besides making room for people like Novak and Lapidus, also made it possible to reprogramme plots.

The basic infrastructural investments, the general generic grid-structures, and the way the grid was utilised in practise, emphasise several important discussions regarding strategic planning (or more precisely integrated tourism planning). In Miami Beach the basic infrastructure was to a great extent planned and carried out by private developers. This development model has often led to large areas being planned and organised on the basis of one particular and often narrow business logic. And very often, the consequence of this logic is that entire districts (and the district's architecture) have been targeted towards a very specific audience. In other words the result is large mono-functional areas which have difficulties in adapting to changing market conditions (with regard to a changed social composition as well as to changed rhythms and forms of application). However, this was and is not the case in Miami Beach.

The flexibility of Miami Beach lay in the fact that the early pioneers importantly, there were more than one - chose the archetypical and very general grid as a point of departure. The consequent use of the grid made Miami Beach easily adaptable to the changing market conditions.

\section{Urban Lobbies and Hedonistic Territories}

Figure 10. A Hypothetical Example. The Principle Diagram Shows the MiamiResorts as Interfaces - Zones Linking the Street, the 'Urban Living Room' and the Garden, Pool and Beach

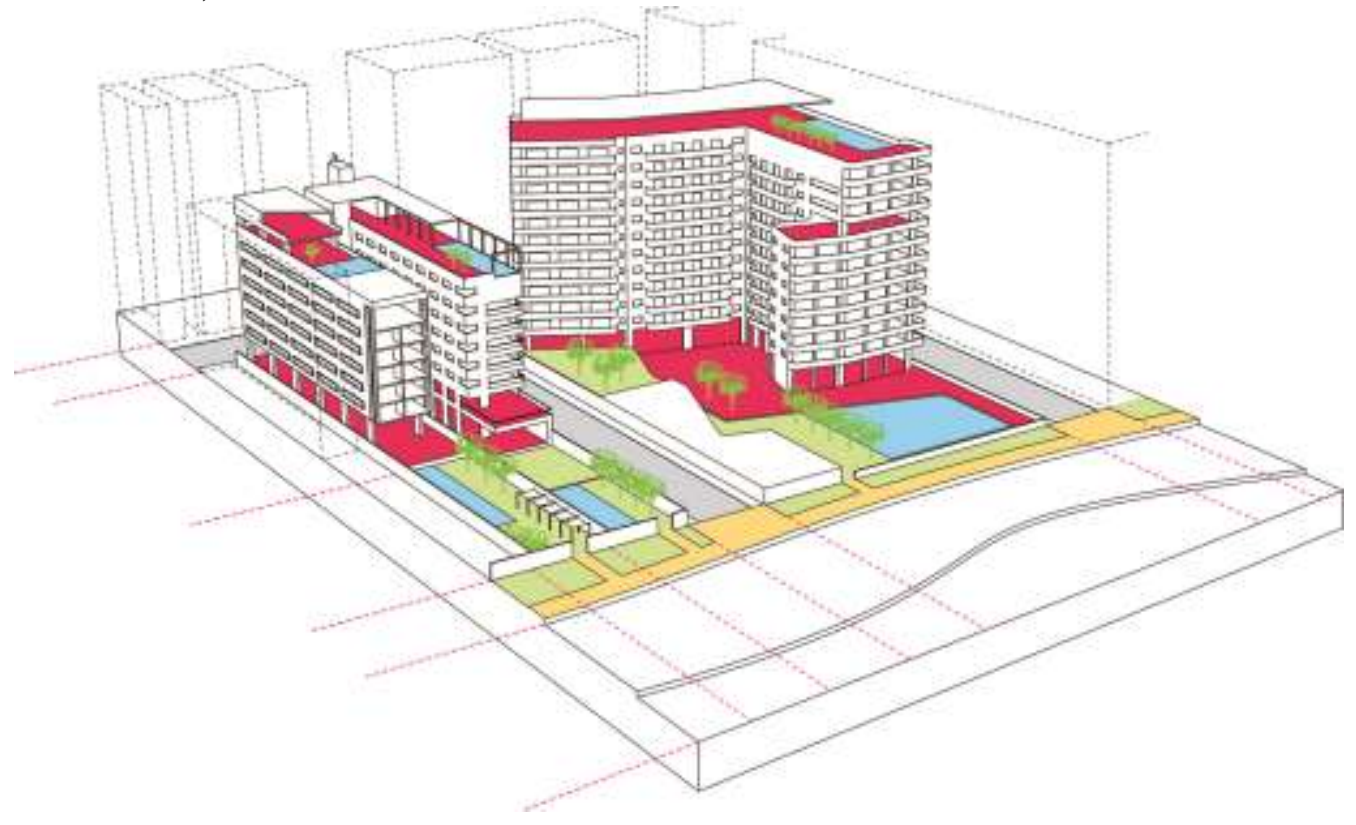


A second lesson from Miami Beach regards the role played by the lobbies and ground floors of the Art Deco hotels and the MiMo resort hotels.

As previously described many Miami Beach hotels were composed as a kind of hybrid - oriented both towards the ocean and towards the urban street. In this way the lobby (of the oceanfront hotels) came to function as an interface between the tropical beach and the urban street. A kind of in-between space serving both guests and non-guests. As Miami Beach grew more urban the lobby became an important place to socialise.

While the lobbies of the pre-war Art Deco hotels functioned as urban living rooms, the ground floors of the post-war MiMo-resorts functioned as allinclusive destinations within the destination. The presented MiMo-resorts of Fontainebleau and Eden Roc demonstrated an unprecedented level of sophistication. They were 'hedonistic territories' and appeared as green exotic openings in the otherwise densely developed beach front. The territories were designed to stimulate interaction - it was staged flirting (and as mentioned, for Lapidus, the illusion did not 'represent non-reality').

What is central here is that the hotel-lobbies and the resort-territories were inscribed in an urban fabric, and further that these spaces demonstrated the potential to function as sophisticated meeting grounds. They were seductive tdspaces that managed to unite and benefit from several types of flows - both tourism-dominated, everyday-dominated and business-dominated. And precisely this ability to frame different forms of life made the lobby interesting as a new sort of hybrid space (addressing both the street and the beach). In this way, the tourism industry started to attract other businesses wanting to settle in a context that provided the most attractive climate (both culturally and physically).

In relation to the concept of positive interference, it is interesting that the Fontainebleau Hotel constituted an extraordinary territory that was optimised in order to stimulate social interaction (between people from the higher strata of society). Lapidus, in close cooperation with Novak, had exposed the power of glamour as well as a number of spatial techniques in order to create the ultimate, luxurious, social meeting grounds.

The MiMo-resorts of the 1950s and 1960s had raised the scale, the level of luxury, and the significance of the lobby and the ground floor as a whole.

\section{Final Note}

This case study has been done in order to inspire future strategic planning. The case study on Miami Beach shows that it is essential to pose qualitative demands not just to the urban fabric and immediate context of new hotels but also to the design and management of the specific lobby floors. A certain percentages of these extraordinary territories must be accessible for people with different errands in order to establish positive interference and in order to utilize the lobbies as positive drivers within the urban fabric. 


\section{Bibliography}

Bauman, Z. (1996) From Pilgrim to Tourist - or a short History of identity. In Hall, S. and Gay, P. (eds.) Question of Cultural Identity (pp. 18-35). Sage Publications.

Camber, D. (2001) Foreword. In: Schulman, A.T. \& Lejeune, J.F. (eds.) The Making of Miami Beach: 1933 - 1942. The Architecture of Lawrence Murray Dixon. Rizzoli.

Cook, J.W. and Klotz, H. (1973) Conversations with Architects (Interview with Morris and Alan Lapidus, pp. 147-177). Praeger Publishers.

Düttmann, M. (1992) Morris Lapidus. Architect of the American Dream. In: Düttmann, M. and Schneider, F. (eds.): Morris Lapidus. Architect of the American Dream. Birkhäuser Verlag, 1992.

Feifer, M. (1985) Going Places. London: Macmillan.

Friedman, A.T. (2000) The Luxury of Lapidus. Glamour, Class, and Architecture in Miami Beach. Harvard Design Magazine, Summer 2000, Number 11.

Kvorning, J. (2010) Hybridity. In: Pasgaard, J.C.L. (ed.) Tourism and Strategic Planning. Conference Report (pp. 74-80). Center for Urbanism. The Royal Academy of Fine Arts.

Lapidus, M. (1996) Too much is never enough. Rizzoli International Publications, Inc.

Löfgren, O. (1999) On Holliday. A History of Vacationing. University of California Press.

McCarthy, J. (1975) The man who invented Miami Beach. Carl Fisher's improbable empire. American Heritage, December 1975, Volume 27, Issue 1.

Pasgaard, J.C. (2012) Tourism and Strategic Planning. PhD-dissertation. The Royal Danish Academy of Fine Arts, Schools of Architecture, Design and Conservation.

Plotner K. and Plotner R. (2008) The Fontainebleau Miami \& Las Vegas. Ask a Local. Schiffer Publishing.

Shulman, A.T. (2001) Building and rebuilding: The making of Miami Beach. In: Schulman, A.T. \& Lejeune, J.F. (eds) The Making of Miami Beach: 1933 - 1942. The Architecture of Lawrence Murray Dixon. Rizzoli.

Urry, J. (2002 (original 1990)) The Tourist Gaze. SAGE Publications Ltd. 
